\title{
Stable isotopic analysis of fossil chironomids as an approach to environmental reconstruction: state of development and future
} challenges

\author{
Oliver Heiri', Jos Schilder' and Maarten van Hardenbroek'
}

Heiri O, Schilder J and van Hardenbroek M. 2012. Stable isotopic analysis of fossil chironomids as an approach to environmental reconstruction: state of development and future challenges. Fauna norvegica 31: 7-18.

Remains of chironomid larvae, especially their strongly sclerotized head capsules, can be found abundantly and well preserved in most lake sediment records. These remains mainly consist of chitin and proteins and, since their chemical composition does not seem to be strongly affected by decompositional processes, they can be used to develop palaeoenvironmental reconstructions based on their stable isotopic composition. Here we review available stable isotope studies based on fossil chironomids and indicate future research necessary to further develop this still relatively new research approach. Efforts to produce stable isotope records based on fossil chironomids have mainly examined the elements $\mathrm{H}$, $\mathrm{N}, \mathrm{C}$, and $\mathrm{O}$. They have focussed on (1) developing the methodology for preparing samples for isotopic analysis, (2) laboratory studies cultivating chironomid larvae under controlled conditions to determine the factors affecting their stable isotopic composition, (3) ecosystem-scale studies relating stable isotopic measurements of fossil chironomid assemblages to environmental conditions, and (4) developing first down-core records describing past changes in the stable isotopic composition of chironomid assemblages. These studies have shown that chemical sample pretreatment may affect the isotopic composition for some elements. Laboratory runs suggest that the diet of the larvae influences their stable isotopic composition for $\mathrm{H}, \mathrm{N}, \mathrm{C}$ and $\mathrm{O}$, whereas stable isotopes in the ambient water also strongly influence their oxygen and to a lesser extent hydrogen isotopic composition. These experiments also indicate only minor offsets between the nitrogen and carbon isotopic composition of chironomid soft tissue and the fossilizing head capsules, whereas for hydrogen and oxygen this offset remains to be explored. Though few datasets have been published, the available ecosystem studies and developed down-core sediment records indicate that stable isotopes in chironomid remains have the potential to provide reconstructions of past climatic change $(\mathrm{H}, \mathrm{O})$ and insights into past food web structure, methane production and pollution of lake ecosystems (N, C). Future efforts will be necessary to develop these approaches including more detailed analyses of the effects of sample pretreatment on stable isotope measurements on chitinous fossils, more extensive laboratory studies constraining the effects of external factors (e.g., isotopic composition of food and ambient water, temperature) on stable isotopes in chironomid larvae, and surveys exploring seasonal changes in the isotopic composition of chironomid larvae and assessing how this seasonality influences fossil assemblages. Finally, multi-site field studies relating chironomid $\delta \mathrm{D}, \delta^{15} \mathrm{~N}$, $\delta^{13} \mathrm{C}$ and $\delta^{18} \mathrm{O}$ to parameters such as $\delta^{18} \mathrm{O}$ of precipitation, air and water temperatures, and nutrient and greenhouse gas concentrations in lakes will be necessary to assess the extent to which these stable isotopic approaches can provide quantitative reconstructions of parameters of interest for palaeoclimatological and palaeoenvironmental research.

doi: 10.5324/fn.v31i0.1436. Received: 2012-01-15. Accepted: 2012-06-24.

Published on paper and online: 2012-10-17.

Keywords: Fossil chironomids, stable isotopes, lake sediments, climate change, ecosystem processes

1. Institute of Plant Sciences and Oeschger Centre for Climate Change Research, University of Bern, Altenbergrain 21, CH-3013 Bern, Switzerland

Corresponding author: Oliver Heiri

E-mail: oliver.heiri@ips.unibe.ch 


\section{INTRODUCTION}

Chironomid remains, especially the larval head capsules, can be found abundantly in lake sediments. These exoskeleton fragments, originating from moulting and deceased larvae, are preserved for ten thousands to hundreds of thousands of years at a quality which allows microscopic identification usually to genus, or species morphotype, but sometimes also to species level (Brodersen \& Bennike 2003; Bennike et al. 2005; Brooks et al. 2007). Since lake sediments can be dated with some accuracy using radiometric and other dating methods, these remains can be identified and enumerated to produce records of past changes in chironomid assemblages in lakes. Chironomid larvae are excellent environmental indicators with many species' distribution limited to lakes with particular water chemistry or temperature conditions, or with a particular habitat structure (e.g., Wiederholm 1984; Saether 1979; Eggermont \& Heiri 2012). This, in turn, allows the use of fossil chironomid records for reconstructing past changes in environmental conditions. In recent years fossil chironomids have been amongst the most rapidly developing palaeoecological and palaeolimnological indicators and they have been used for reconstructing past changes in variables such as nutrient concentrations, oxygen availability or temperature in lakes (e.g., Brodersen \& Quinlan 2006, Brooks 2006; Walker \& Cwynar 2006).

Stable isotopic analysis of lake sediment components is another rapidly developing and very successful approach for palaeoenvironmental reconstruction. Since the stable isotopic composition of lake water and the organic matter produced within lakes is influenced by ambient environmental conditions, the analysis of stable isotope pairs such as ${ }^{2} \mathrm{H}$ (or D) $/{ }^{1} \mathrm{H},{ }^{13} \mathrm{C} /{ }^{12} \mathrm{C},{ }^{15} \mathrm{~N} /{ }^{14} \mathrm{~N}$, and ${ }^{18} \mathrm{O} /{ }^{16} \mathrm{O}$ in bulk sediment samples or individual sediment components allows insights into past environmental changes. For example, the analysis of $\delta^{18} \mathrm{O}$ in diatom silica or lacustrine carbonates has been used to infer past climatic changes based on lake sediment records (Leng $\&$ Marshall 2004). Similarly, analysis of $\delta^{13} \mathrm{C}$ and $\delta^{15} \mathrm{~N}$ of bulk organic matter has been used to trace the provenance of sedimentary organic matter (Meyers \& Lallier-Vergès 1999) and to reconstruct past nitrogen pollution in lakes (Leavitt et al. 2006). Chironomid cuticles consist largely of chitin and proteins and the chemical composition of these structures seems to be largely unchanged even in head capsules over ten thousand years old (Verbruggen et al. 2010a). Chironomid remains preserved in lake sediments are therefore of interest for palaeoenvironmental reconstruction based on stable isotopic analyses. In contrast to many other sediment components, both chitin and proteins include relatively large amounts of nitrogen. Therefore, all the elements commonly analysed for stable isotopes in a palaeolimnological context $(\mathrm{H}, \mathrm{C}, \mathrm{O}, \mathrm{N})$ could be analysed on the same material. Furthermore, since chironomid head capsules can be easily pre-identified under the microscope, non-lacustrine chironomid taxa, belonging to rheophilous, semi-terrestrial or terrestrial groups, can be excluded when preparing samples for analysis. Therefore, the approach may not be as susceptible to contamination from terrestrial or running water sources as stable isotopic analyses of other sediment components such as diatom silica (sometimes affected by contamination with clay minerals) (Leng \& Barker 2006) and aquatic cellulose (potentially affected by contamination with terrestrial cellulose) (Wolfe et al. 2001). Wooller et al. (2004) provided the first stable isotopic record based on fossil chironomids. They analysed $\delta^{18} \mathrm{O}$ in chironomid remains obtained from surface sediments in four lakes in North America and showed that chironomid $\delta^{18} \mathrm{O}$ was related to mean annual air temperature at these sites. Furthermore, they presented down-core records of chironomid $\delta^{18} \mathrm{O}$ which indicated major changes in this variable during the past 100,000 years. Wooller et al.'s (2004) study demonstrated the potential of this new approach: Since both chironomid $\delta^{18} \mathrm{O}$ and changes in the taxonomic composition of chironomid assemblages provide information on past climatic changes they were able to produce two independent temperature reconstructions based on the same indicator group. Changes in the chironomid assemblage composition allowed past surface water temperatures to be estimated using a palaeoecological approach whereas variations in chironomid $\delta^{18} \mathrm{O}$ provided a mean annual temperature reconstruction based on the modern relationship between air temperature and $\delta^{18} \mathrm{O}$ of precipitation.

Since Wooller et al.'s (2004) pioneering work several additional studies focusing on stable isotopes in chironomid remains have been published (Wooller et al. 2008, 2012; Wang et al. 2008; Griffiths et al. 2010; van Hardenbroek et al. 2010, 2012a, b; Verbruggen et al. 2010a, 2011). It is expected that this approach will become more popular and widely applied once the initial methodology has been developed and the necessary calibration studies and calibration datasets have been produced. Here we review the development of the approach in recent years and discuss both the difficulties and the potential of stable isotopic analyses based on chironomid remains. We believe the major challenge will not only be to develop the methodology to a degree that stable isotopes can be measured reliably on fossil chironomid remains, but also to produce robust and widely applicable datasets that describe the fractionation factors and offsets in isotopic values between the fossils, the living animal tissue and the environment in which the larvae live. We will provide some examples demonstrating how, in our opinion, additional steps towards a mechanistic understanding of the factors influencing stable isotopic composition in chironomid cuticles can be achieved. Finally we will briefly review the available down-core records of the stable isotopic composition of fossil chironomids and provide a brief outlook on expected and necessary future developments within this young research field.

\section{The challenge}

The stable isotopic composition of organic structures of lakeliving invertebrates, at least in respect to the four elements $\mathrm{H}$, 
$\mathrm{C}, \mathrm{N}$, and $\mathrm{O}$, is mostly determined by the isotopic composition of the lake water $(\mathrm{H}$ and $\mathrm{O})$ and the diet of the animals $(\mathrm{C}, \mathrm{N}$, and to a lesser extent $\mathrm{H}$ and O). Schimmelmann (2011) recently reviewed the relationship between $\delta^{13} \mathrm{C}, \delta^{15} \mathrm{~N}$, and $\delta^{18} \mathrm{O}$ of diet and chitinous tissues of various terrestrial and aquatic arthropods. However, detailed studies dealing with strictly limnic invertebrate groups, and especially Chironomidae, are still relatively rare. Nielson and Bowen (2010) have shown that the $\delta^{18} \mathrm{O}$ of brine shrimp (Artemia franciscana) chitin is mainly influenced by the isotopic composition of the ambient water, whereas $\delta^{18} \mathrm{O}$ of the food ingested by these invertebrates played only a relatively minor role. In contrast, $\delta \mathrm{D}$ of brine shrimp chitin seemed strongly influenced by both food and water. Wang et al. (2009) demonstrated in laboratory studies that both diet and the stable isotopic composition of the ambient water influence $\delta^{18} \mathrm{O}$ and $\delta \mathrm{D}$ of chironomid larvae, with the isotopic composition of ambient water again having a stronger influence on chironomid $\delta^{18} \mathrm{O}$ than on $\delta \mathrm{D}$. Laboratory studies with chironomids also indicate that $\delta^{15} \mathrm{~N}$ and $\delta^{13} \mathrm{C}$ of their soft tissues can be predicted with a high degree of confidence if the isotopic composition of the food of the larvae is known (Goedkoop et al. 2006), suggesting that the stable isotopic composition of inorganic $\mathrm{C}$ and $\mathrm{N}$ does not affect $\delta^{13} \mathrm{C}$ and $\delta^{15} \mathrm{~N}$ of the larvae. However, additional laboratory cultivations of chironomid larvae, ideally from a range of different species and taxonomic groups, covering a range of isotopic values of the food and ambient water, and implemented under varying environmental conditions, especially with respect to temperature, will be necessary to confirm these results. For chironomid isotopic techniques to be used for palaeoenvironmental reconstruction additional information and research is needed. First, the offset between soft tissue of the larvae, which is usually analysed for stable isotopes in hydrobiological laboratory and field studies, and the sclerotized, chitinous head capsules, the fossilizing structure of the larvae, will have to be established. Whereas this offset will most likely be minor for some elements, such as $\mathrm{C}$, it may be considerably larger for other elements such as $\mathrm{O}$ or $\mathrm{H}$. Second, sample preparation techniques will have to be developed which do not affect the isotopic composition of chironomid fossils. Alternatively, techniques which influence the isotopic composition of the remains may be acceptable if these effects can be corrected for. Again, one can expect that different sample preparation techniques, especially chemical pretreatments, will affect the isotopic composition of different elements to a varying degree. Once the relationship between isotopic composition of fossilizing structures and larval soft tissues is known, and any potential methodological errors are quantified, it will be possible to calculate the expected stable isotopic composition of formerly living larvae based on measurements on fossil remains. For stable isotope pairs with available, published data for chironomids, such as ${ }^{13} \mathrm{C} /{ }^{12} \mathrm{C}$ and ${ }^{15} \mathrm{~N} / 14 \mathrm{~N}$, this may already allow a first interpretation of changes in fossil chironomid stable isotopic values. However, a reliable interpretation of fossil records will have to take into account the role of taphonomy and seasonality in shaping fossil assemblages. Biotic remains produced in lakes can be transported to some extent, usually towards deeper sections of the lake basin, before they are incorporated into sediments (e.g., van Hardenbroek et al. 2011). At the same time the production of fossilizing structures in chironomids, as in most other lacustrine organism groups, is not uniform over the year and, depending on the species involved, may be biased towards certain periods within the annual cycle. Since they incorporate fossils produced in different parts of the lake and during different seasons, fossil assemblages in lake sediments represent both spatially and temporally integrated samples (Frey 1988). Therefore, any interpretation of fossil chironomid isotopic records, usually based on compound samples consisting of many chironomid head capsules, will have to take account of these processes and isotopic measurements based on fossil assemblages may only be comparable to a limited extent with measurements based on individual larvae collected in contemporary lake ecosystems. Calibration datasets based on lake surface sediment allow a direct comparison of isotopic measurements on selected sediment components with environmental parameters measured in contemporary aquatic ecosystems (e.g., water chemistry and the isotopic values of available food and water in lakes) (e.g., Herzschuh et al. 2010; Verbruggen et al. 2011; van Hardenbroek et al. 2012a, b). Such datasets will be necessary for up-scaling measurements based on fossil chironomid remains to allow reconstructions of past environmental changes in lakes and their environment.

\section{METHODOLOGY}

\section{Sample preparation, sample pretreatment, sample sorting, minimum sample weight}

Methods for obtaining lake sediment cores and for dating these records have been developed and tested over decades and do not need to be modified to work with chironomid-based stable isotopic approaches (e.g., Last \& Smol 2001). Physical and chemical pretreatment methods facilitating the sorting of micro- and macrofossils from sediments, often the most time-consuming step when analysing fossil remains, have similarly been developed over years and tested for a range of fossil groups. For fossil chironomid analysis, sediment sample pretreatment typically involves the use of chemical reagents to eliminate some sedimentary components (e.g., carbonates) and loosen the sediment structure, followed by washing of sediments on a 90-100 $\mu \mathrm{m}$ mesh sieve (e.g., Walker 2001; Brooks et al. 2007). The sieve residue is then examined for chironomid fossils under a stereomicroscope (typically at 2550x magnification) and fossil remains of interest are picked from the other sieve residue using fine forceps. For chironomid stable isotope analysis, remains are typically sorted directly into tin or silver cups suitable for isotope ratio mass spectrometry (IRMS). The stable isotopic composition of the samples is then 
analysed using IRMS, together with samples of standards with known isotopic composition. If wet samples are sorted under the stereomicroscope distilled water is usually used. The tin or silver cups should be pre-weighed and usually the fossils will be transferred by forceps into a drop of distilled water within the cups. The water is evaporated at room temperature, in a drying cabinet at higher temperatures (typically $<50^{\circ}$ ) or in a freeze drier. The cups can then be re-weighed to provide an estimate of the sample mass. Blank measurements on tin or silver cups which were filled with a similar amount of distilled water from the sieved samples as cups containing chironomid remains are important to double check whether this procedure leads to detectable contamination in the dried samples by carbonate, or organic precipitates (e.g., van Hardenbroek et al. 2012a). For analyses of $\delta^{18} \mathrm{O}$ and $\delta \mathrm{D}$ it may be advisable that samples are stored in a desiccator after drying. Microscopic analyses of fossil chironomids are not affected by mild chemical pretreatments (e.g., $10 \% \mathrm{KOH}$ or $\mathrm{HCl}$ solution) as long as the morphology of larval head capsules is not affected. However, the chemical composition of fossils can be modified by these pretreatments even if the morphology is not. As a consequence it is important to establish that the applied pretreatment methods do not affect the stable isotopic composition of the remains. Wooller et al. (2004) tested whether $\delta^{18} \mathrm{O}$ of purified chitin is affected by standard $\mathrm{HCl}$ and $\mathrm{KOH}$ treatment used in chironomid analysis and could not detect a significant effect. In contrast, in experiments with head capsules of Chironomus riparius, Verbruggen et al. (2010a) were able to show that both alkali and acid treatments can affect the chemical composition of chironomid cuticles and also their $\delta^{18} \mathrm{O}$ values. A noticeable effect was detected even with relatively low concentrations of $\mathrm{KOH}(10 \%)$, although strong effects were restricted to treatments with very high concentration acid and alkali treatments (Figure 1a). Verbruggen et al. (2010a) recommend not to use strong acid and alkali treatments and chemical treatments at higher than room temperature for chironomid $\delta^{18} \mathrm{O}$ analysis. These results suggest that chironomid $\delta^{18} \mathrm{O}$ should perhaps best be attempted without any chemical pretreatment of the fossils. However, in a second study Verbruggen et al. (2010b) showed that chironomid fossils prepared for $\delta^{18} \mathrm{O}$ analyses may be contaminated by residual carbonate matter, especially if they originate from sediments with a high carbonate content such as lake marls. They demonstrated that these residual carbonates interfere with $\delta^{18} \mathrm{O}$ measurement and, in an experiment with isotopically heavy water, showed that acid treatment can affect $\delta^{18} \mathrm{O}$ of chironomid cuticles. Verbruggen et al. (2010b) instead recommend treatment with buffered $2 \mathrm{M} \mathrm{NH} \mathrm{NH}_{4} \mathrm{Cl}$ solution to dissolve residual carbonates at a $\mathrm{pH}$ of 7.5. Van Hardenbroek et al. (2010) tested the effects of a number of pretreatment methods on $\delta^{13} \mathrm{C}$ of chironomid cuticles, including exposure to $10 \%$ $\mathrm{KOH}, 10 \% \mathrm{HCl}$, and $40 \% \mathrm{HF}$ solution, and a mixed procedure with accelerated solvent extraction followed by a treatment with sodium chlorite and glacial acetic acid (Figure 1b). They were able to show that these treatments had only a small effect on chironomid cuticle $\delta^{13} \mathrm{C}$ and measured values for all of these treatments were within a range of $1.2 \%$. The authors concluded that, in contrast to $\delta^{18} \mathrm{O}$ analyses, $\delta^{13} \mathrm{C}$ measurements were affected by standard chemical pretreatments only to a limited extent, indicating that mild treatments with, e.g., $10 \% \mathrm{HCl}$ or $10 \% \mathrm{KOH}$ solution for a few hours only should not affect $\delta^{13} \mathrm{C}$ of fossil chironomid remains.

The examples discussed here demonstrate that chemical pretreatments can affect the results of stable isotopic analyses. However, they also show that the effects of an individual pretreatment strongly depend on the element and stable isotope of interest. Based on the available results $\delta^{18} \mathrm{O}$ measurements seem more strongly affected than $\delta^{13} \mathrm{C}$. For $\delta^{15} \mathrm{~N}$ only few data are presently available. Effects on $\delta \mathrm{D}$ have not yet been investigated. The conclusions for future stable isotope analyses based on fossil chironomids seem clear. Analysts should follow established pretreatment protocols to ensure that their measurements are compatible with earlier results. If chemical pretreatment methods are modified it is important to test whether this affects the stable isotopic composition of the samples. Furthermore, chemical pretreatment testing should certainly be extended and refined in the future. For example, it remains unclear at what concentrations or $\mathrm{pH}$ treatments with $\mathrm{HCl}$ lead to noticeable changes in chironomid cuticle $\delta^{18} \mathrm{O}$ and whether acid treatment should be avoided altogether. Similarly, a systematic and complete survey of the effects of different chemical treatment types, concentrations and exposure times for the full range of chemical pretreatments commonly used in chironomid Palaeoecology (e.g., solutions of $10 \% \mathrm{HCl}, 10 \% \mathrm{KOH}, 40 \% \mathrm{HF}, 2 \mathrm{M} \mathrm{NH} \mathrm{N}_{4} \mathrm{Cl}$ ) (Walker 2001; Brooks et al. 2007; Verbruggen et al. 2010a, b) yet remains to be established for the different elements and isotopes of interest (D, ${ }^{13} \mathrm{C},{ }^{15} \mathrm{~N},{ }^{18} \mathrm{O}$ ).

The number of fossils needed for analysis is perhaps the most crucial methodological question for research projects assessing the stable isotopic composition of chironomid remains. The minimum sample mass for analyzing stable isotopes on organic matter strongly depends on the quality and nature of the analytical equipment available and the element of interest. Replicate measurements of chitin standards with a known isotopic composition or of chironomid head capsules of cultivated larvae are usually necessary to assess the minimum sample size for a given analytical procedure. For example, Verbruggen et al. (2010a) used samples of purified chitin and Chironomus riparius head capsules, cleaned of soft tissue manually with forceps and with a mild treatment with $10 \%$ $\mathrm{KOH}$ solution, to assess the minimum weight needed for $\delta^{18} \mathrm{O}$ analysis using a high-temperature conversion (TC) elemental analyzer (EA) coupled to an IRMS. They concluded, based on replicate measurements of different weight, that a minimum sample weight of ca. 40-50 $\mu \mathrm{g}$ was necessary for $\delta^{18} \mathrm{O}$ analysis. Van Hardenbroek et al. (2010) used a similar experimental setup to determine the minimum sample mass for $8^{13} \mathrm{C}$ analysis of chironomid remains. They concluded that a minimum of ca. 
A

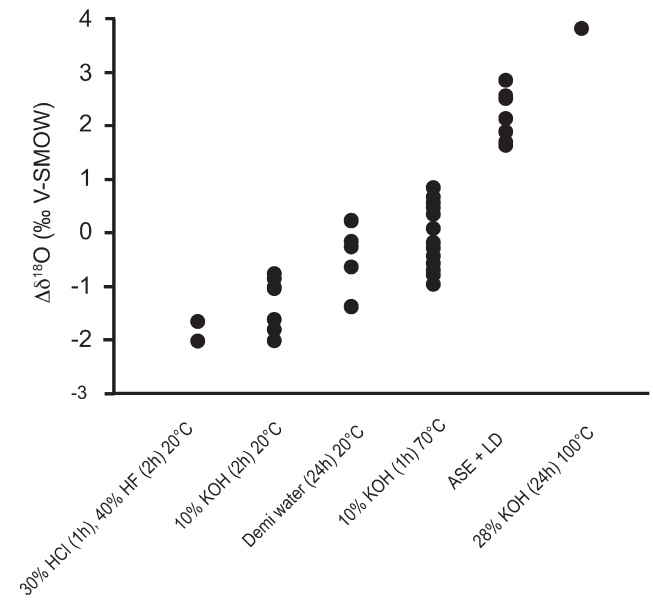

B

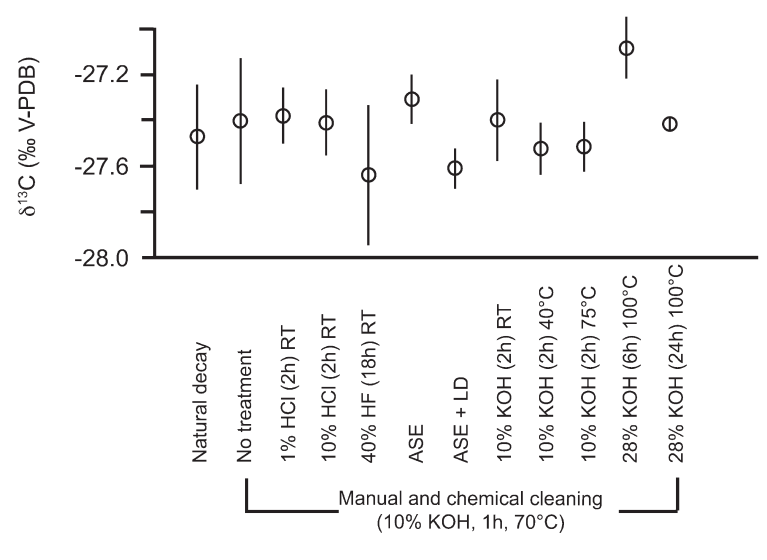

Figure I. A) Effects of some different chemical pretreatments on the stable oxygen isotopic composition of head capsules of Chironomus riparius. Values are plotted relative to head capsules exposed for $1 \mathrm{~h}$ in a $10 \% \mathrm{KOH}$ solution at $70^{\circ} \mathrm{C}$. B) Effects of different pretreatment types on the carbon isotopic composition of Chironomus riparius head capsules. Circles and vertical bars indicate means and standard deviations of replicate measurements, respectively. ASE indicates accelerated solvent extraction, LD the treatment with sodium chlorite and glacial acetic acid described by Leavitt \& Danzer (1993) and RT room temperature. Data for A from Verbruggen et al. (2010a), and for B from van Hardenbroek et al. (2010).

Table I. Average and range of chironomid head capsule (HC) weights for different chironomid taxa calculated from $\mathrm{n}$ taxon-specific chironomid samples. Surface sample values are from van Hardenbroek et al. (2012a, b). Down-core sample values are from van Hardenbroek et al. (2010; 2012b). Note that the instar distribution may have varied considerably in the examined sediments and this may explain the large differences in the mean $\mathrm{HC}$ weight recorded for the same taxa in surface and down-core samples.

\begin{tabular}{|c|c|c|c|c|c|c|}
\hline \multirow[b]{2}{*}{ Taxon } & \multicolumn{3}{|c|}{ Surface samples } & \multicolumn{3}{|c|}{ Down-core samples } \\
\hline & $\begin{array}{c}\text { Mean } \mathrm{HC} \text { weight } \\
(\mu \mathrm{g})\end{array}$ & $\begin{array}{c}\text { Range } \\
(\mu \mathrm{g})\end{array}$ & $\mathrm{n}$ & $\begin{array}{c}\text { Mean } \mathrm{HC} \text { weight } \\
(\mu \mathrm{g})\end{array}$ & $\begin{array}{c}\text { Range } \\
(\mu \mathrm{g})\end{array}$ & $\mathrm{n}$ \\
\hline Chironomus spp. & 3.5 & $1.1-16.0$ & 18 & 1.2 & $0.3-2.2$ & 30 \\
\hline Chironomini & 3.0 & $0.6-21.0$ & 23 & 0.8 & $0.4-1.5$ & 41 \\
\hline Corynocera ambigua & & & & 1.3 & $1.2-1.5$ & 7 \\
\hline Tanytarsini & 1.0 & $0.3-2.6$ & 26 & 0.6 & $0.3-1.1$ & 33 \\
\hline Orthocladiinae & 1.0 & $0.4-2.3$ & 26 & 0.8 & $0.1-2.5$ & 22 \\
\hline Tanypodinae & 1.6 & $0.5-4.0$ & 17 & 1.0 & $0.5-1.4$ & 17 \\
\hline
\end{tabular}

$20 \mu \mathrm{g}$ was needed to produce a reliable signal for the EA-IRMS equipment available for their measurements. Estimating the number of fossils necessary for an individual measurement based on these minimum weight requirements is complicated by the different size and weight of larval head capsules of different chironomid species and instars. For example, our measurements indicate that the mass of a fourth instar larval head capsule of the large chironomid species Chironomus riparius is ca. 3-4 $\mu$ g. However, the head capsules of younger instars and smaller specimens, e.g. Orthocladiinae, will weigh only a fraction of this amount. Depending on the species and instar composition, one larval head capsule may be equivalent to $\sim 0.1$ to $21.0 \mu \mathrm{g}$ (Table 1).

\section{Rearing experiments: Relating fossil isotopic composition to larval} tissue, food and ambient water

Rearing experiments are essential for relating stable isotopic analyses of biotic remains to the environmental conditions during the former growth and life of the fossilizing organisms. For example, rearing experiments are available relating $\delta^{18} \mathrm{O}$ of fossilizing structures of lake-living organism groups such as diatoms (e.g., Brandriss et al. 1998) and ostracods (e.g., von Grafenstein et al. 1999) to the stable isotopic composition of lake water. These experiments have revealed indicator groupspecific and in many cases more restricted, taxon-specific offsets between $\delta^{18} \mathrm{O}$ of the organism of interest and its environment. For chironomids, a substantial number of modern ecological studies are available that provide information on $\delta^{13} \mathrm{C}$ and $\delta^{15} \mathrm{~N}$ 
of individual larvae in a range of environments and in different ecosystem types (see, e.g., Grey et al. 2004a, b; Borderelle et al. 2008; Jones et al. 2008). These measurements are usually based on samples taken from the larval body. However, an offset in isotopic values between the strongly sclerotized cuticle of the head capsule and the soft tissue of chironomid larvae is possible. To correctly interpret the findings of these modern ecological surveys for palaeoecological studies it is therefore also necessary to quantify this offset.

For chironomids, experimental studies relating the isotopic composition of their environments to the isotopic composition of the larval tissue are available for the elements and stable isotopes of most interest in a palaeoecological context. Wang et al. (2009) studied the effects of $\delta^{18} \mathrm{O}$ and $\delta \mathrm{D}$ of lake water and food on the stable isotopic composition of cultured Chironomus dilutus larvae (Figure 2C-D). Based on these experiments they estimated that ca. $69 \%$ of the $\mathrm{O}$ and ca. $31 \%$ of the $\mathrm{H}$ in the larvae originate from the habitat water, the residual presumably

\section{A}

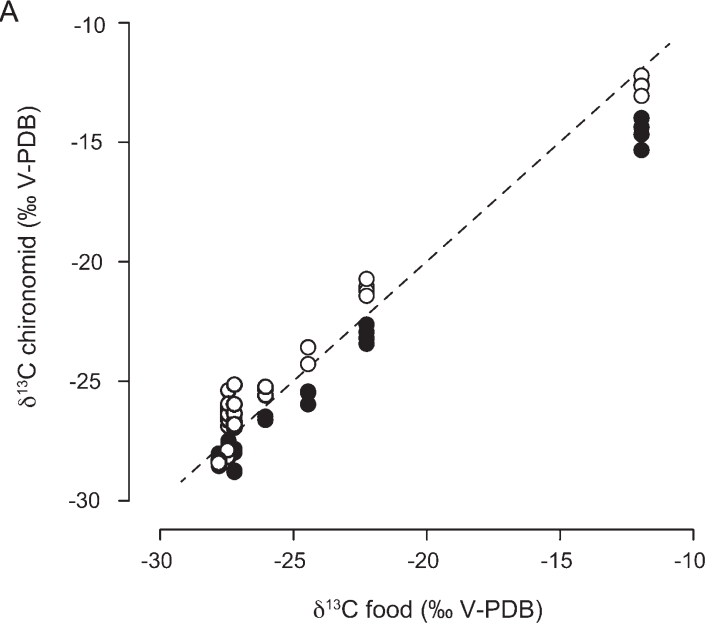

C

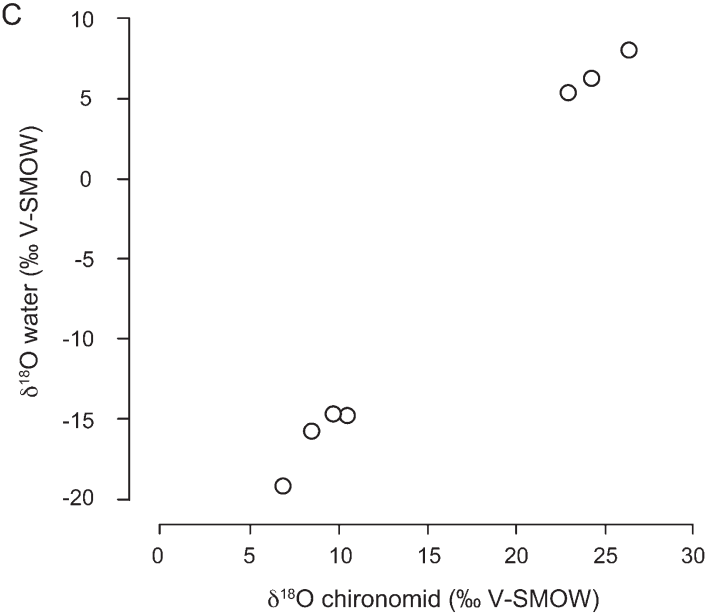

originating from food. Goedkoop et al. (2006) studied the effects of the stable isotopic composition of diet on $\delta^{15} \mathrm{~N}$ and $\delta^{13} \mathrm{C}$ of Chironomus riparius. Since inorganic $\mathrm{C}$ and $\mathrm{N}$ were not expected to influence the results, the isotopic composition of these parameters was not controlled in the experimental runs. The authors demonstrated that $\delta^{13} \mathrm{C}$ and $\delta^{15} \mathrm{~N}$ in the larval tissues were very similar to food ingested by the larvae, with $\delta^{15} \mathrm{~N}$ even more similar to the isotopic composition of the diet than expected based on prior food web studies. However, the authors cautioned that $\delta^{15} \mathrm{~N}$ of food in their experimental systems seemed to be strongly modified by microbial activity. To our knowledge no detailed studies are presently available that quantify the offset between the stable isotopic composition of the fossilizing structures of chironomid larvae and their soft tissue. In a range of unpublished experiments we provided larvae of Chironomus riparius with a range of food sources originating from both $\mathrm{C}-3$ and $\mathrm{C}-4$ plants or consisting of yeast grown on sugars from $\mathrm{C}-3$ or $\mathrm{C}-4$ plants. The results of these
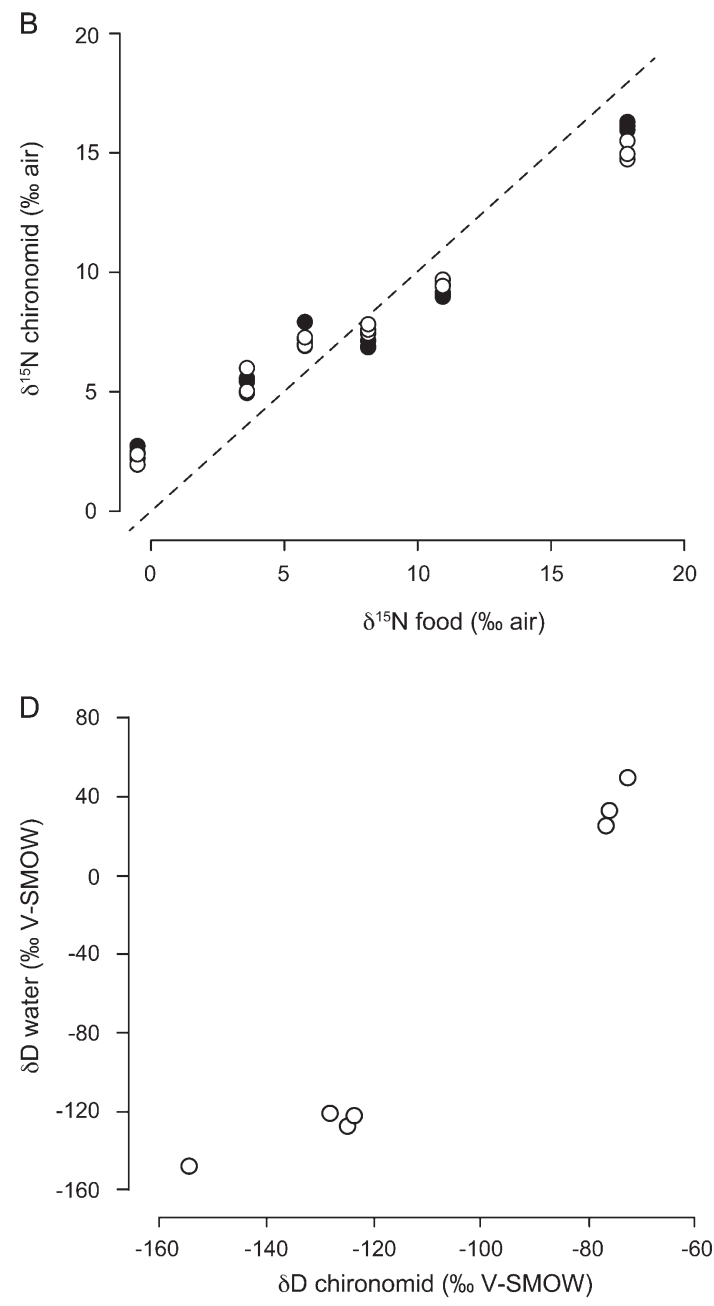

Figure 2. A-B) Relationship between the stable isotopic composition of chironomid head capsules (closed circles), soft tissue (open circles) and the food ingested by the larvae as assessed for $\delta^{13} \mathrm{C}$ and $\delta^{15} \mathrm{~N}$ in a series of controlled laboratory experiments with Chironomus riparius. C-D) Relationship between $\delta^{18} \mathrm{O}$ and $\delta \mathrm{D}$ in larvae of Chironomus dilutus and the water they were cultivated in as indicated based on controlled laboratory experiments. A-B unpublished data, C-D redrawn from from Wang et al. (2009). 
A

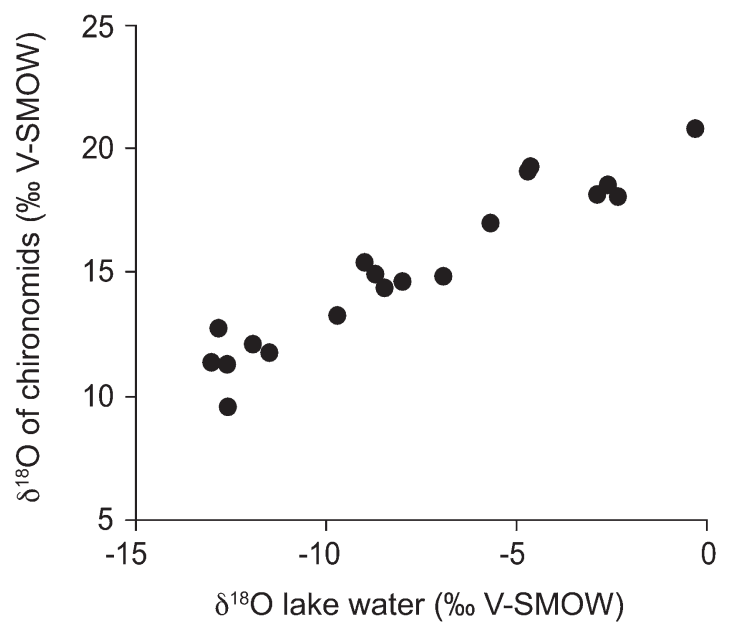

B

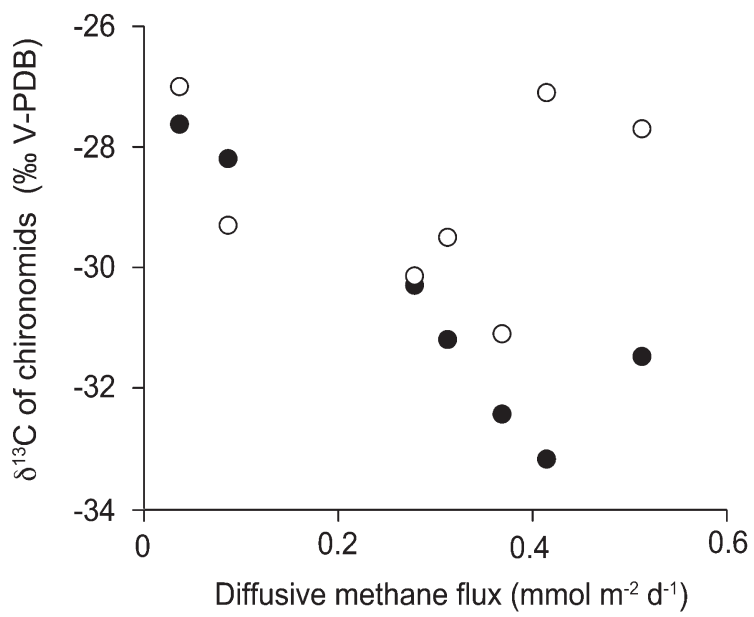

Figure 3. A) Relationship between $\delta^{18} \mathrm{O}$ of chironomid remains in lake surface sediments and $\delta^{18} \mathrm{O}$ of the lake water in 31 deep and stratified lakes in Europe (redrawn from Verbruggen et al. 2011). B) Relationship between methane flux measured at the lake surface and $\delta^{13} \mathrm{C}$ of subfossil remains of Chironomini (closed circles) and Orthocladiinae (open circles) in the surface sediments of 7 lakes in southern central Sweden (data from van Hardenbroek et al. 2012a).

experiments confirm the findings of Goedkoop et al. (2006) that $\delta^{13} \mathrm{C}$ and $\delta^{15} \mathrm{~N}$ of chironomid larvae is strongly related to the stable isotopic composition of their food, although in our experiments the relationship was stronger and closer to unity for $\delta^{13} \mathrm{C}$ than for $\delta^{15} \mathrm{~N}$ (Figure 2A-B). Again, microbial activity is a potential influencing factor which may have modified $\delta^{15} \mathrm{~N}$ of food available to the larvae within the experimental tanks. Furthermore, our experiments revealed that $\delta^{13} \mathrm{C}$ and $\delta^{15} \mathrm{~N}$ of the head capsules are very similar to the stable isotopic composition of the larval soft tissue, with an offset of $\sim 1 \% 0$ apparent for both $\delta^{13} \mathrm{C}$ and $\delta^{15} \mathrm{~N}$ (Figure 2A-B). These results indicate that for $\mathrm{C}$ and $\mathrm{N}$ the stable isotopic composition of fossil chironomid assemblages can be directly compared with the isotopic values measured on entire chironomid larvae in modern ecological studies as long as this offset is taken into account.

The few rearing and culturing experiments presently available highlight the need for additional studies exploring the relationship between the stable isotopic composition of chironomid larvae, the larval head capsules and the food and water to which the larvae are exposed. Available results indicate that chironomid $\delta^{13} \mathrm{C}, \delta^{15} \mathrm{~N}, \delta^{18} \mathrm{O}$ and $\delta \mathrm{D}$ are closely and systematically related to the isotopic composition of the food ingested by the larvae and, for $\delta^{18} \mathrm{O}$ and $\delta \mathrm{D}$, of the lake water. For $\delta^{13} \mathrm{C}$ and $\delta^{15} \mathrm{~N}$ first results indicate a very minor offset between the isotopic composition of the head capsule and of the remaining tissue, whereas for $\delta^{18} \mathrm{O}$ and $\delta \mathrm{D}$ this offset remains to be explored. However, to date no information is available concerning the effects of temperature on the stable isotopic composition of the larvae relative to their food and ambient water. A direct temperature dependent fractionation during the formation of the cuticle, as observed during the formation of biogenic carbonate and silicate structures, is not expected for organic structures. Nevertheless the strong influence of temperature on a range of physiological processes in the larvae and their environments makes an indirect temperature effect possible. Future experimental studies should therefore focus on determining the offset between the stable isotopic composition of chironomids and their head capsules for $\delta \mathrm{D}$ and $\delta^{18} \mathrm{O}$ and on determining the effects of temperature on larval chironomid $\delta \mathrm{D}, \delta^{13} \mathrm{C}, \delta^{15} \mathrm{~N}$ and $\delta^{18} \mathrm{O}$.

\section{Ecosystem-scale studies}

Studies examining the stable isotopic composition of chironomid remains deposited in lakes and linking these measurements to environmental conditions within and around lakes are still rare. Wooller et al. (2004), in their pioneering study, analysed $\delta^{18} \mathrm{O}$ of chironomid remains in the surface sediments of four lakes along the North American east coast. They demonstrated that $\delta^{18} \mathrm{O}$ of chironomid head capsules was correlated with $\delta^{18} \mathrm{O}$ of precipitation. Their study confirmed that chironomid $\delta^{18} \mathrm{O}$ can provide insights into past changes in $\delta^{18} \mathrm{O}$ of precipitation, and, indirectly, on past climatic changes. Verbruggen et al. (2011) examined the relationship between $\delta^{18} \mathrm{O}$ of chironomid and cladoceran remains, lake water, and expected precipitation for 31 lakes in Europe. These lakes covered a wide range in latitude and, consequently, also in lake water $\delta^{18} \mathrm{O}$. Verbruggen et al. (2011) showed that a correlation exists between expected $\delta^{18} O$ in precipitation and $\delta^{18} \mathrm{O}$ of both chironomid and cladoceran remains deposited in these lakes. However, invertebrate $\delta^{18} \mathrm{O}$ was even more closely and linearly related to $\delta^{18} \mathrm{O}$ of lake water (Figure 3A). The authors concluded that both chironomid and cladoceran remains can provide insights into past lake water $\delta^{18} \mathrm{O}$ changes. An interesting finding was that the examined cladoceran remains, mainly the ephippia (resting eggs) of 
Daphnia, had $\delta^{18} \mathrm{O}$ values which were consistently lower than measured for the chironomid head capsules. This may reflect that chironomid and cladoceran remains may be produced in different seasons and habitats in the lake, or the offset may be related to different diet and metabolism or to a different chemical composition and microstructure of the remains. Considering the large variations in lake water $\delta^{18} \mathrm{O}$ observed within lakes during the seasonal cycle and between habitats, seasonality and habitat preference seem the most likely explanation for this offset, although detailed studies of the spatial and temporal variability of $\delta^{18} \mathrm{O}$ of different invertebrate taxa in lakes will be necessary to further explore this hypothesis.

In contrast to studies on $\delta^{18} \mathrm{O}$ of fossil chironomid assemblages, which cannot rely on any published surveys of the isotopic composition of modern chironomid larvae, a number of studies have examined $\delta^{13} \mathrm{C}$ and $\delta^{15} \mathrm{~N}$ of aquatic invertebrates, including chironomids, in lakes (e.g., Grey 2006; Jones et al. 2008). These studies have shown that $\delta^{13} \mathrm{C}$ in aquatic invertebrates mainly reflects the isotopic composition of the food ingested by the larvae and ultimately the organic carbon source. ${ }^{15} \mathrm{~N}$ is also strongly related to the basal nitrogen source. However, $\delta^{15} \mathrm{~N}$ values are also affected by the trophic level of the organisms within a food web (Minagawa \& Wada 1984; Post 2002). $\delta^{13} \mathrm{C}$ and $\delta^{15} \mathrm{~N}$ of chironomid larvae can be very variable, ranging from -72.3 to $-15.1 \%$ for $\delta^{13} \mathrm{C}$ and -7.8 to $15.6 \%$ for $\delta^{15} \mathrm{~N}$ (Grey et al. 2004b; Harrod \& Grey 2006; Jones et al. 2008). A major reason for the variability of $\delta^{13} \mathrm{C}$ in chironomids is that the carbon isotopic composition of algae can be very variable, ranging from values as low as $-44.1 \%$ in exceptional circumstances to $-8.2 \%$ (e.g., Beaudoin et al. 2001; Pel et al. 2003). In addition, chironomid larvae of some genera, e.g., Chironomus, Stictochironomus and Propsilocerus, seem to be able to produce a significant amount of their biomass from organic carbon originating from methane (Kiyashko et al. 2001; Grey et al. 2004b; Jones et al. 2008; Ravinet et al. 2010). In lakes, methane is characterized by very low (depleted) $\delta^{13} \mathrm{C}$ values ranging from -80 to $-50 \%$ (Whiticar et al. 1986) and can be oxidized and fixed by methane-oxidizing (methanotrophic) bacteria (MOB). As a consequence, organisms feeding on these MOB may have exceptionally low $\delta^{13} \mathrm{C}$ values. Laboratory and field studies have shown that, e.g., larvae of Chironomus can be characterized by $\delta^{13} \mathrm{C}$ values as low as $-72.3 \%$ (Jones et al. 2008), and that carbon of methanotrophic bacteria is ingested and incorporated into larval biomass (Deines et al. 2007a, b). Van Hardenbroek et al. (2010) demonstrated that, since methanogenic carbon can be incorporated into the larval head capsules as well, $\delta^{13} \mathrm{C}$ measurements on fossil chironomid remains may have the potential to provide insights into the past methane availability and abundance in lakes. To explore this issue further van Hardenbroek et al. (2012a) studied $\delta^{13} \mathrm{C}$ of chironomid remains in lake surface sediments in seven Swedish lakes. They showed that $\delta^{13} \mathrm{C}$ of Orthocladiinae tended to be higher than $\delta^{13} \mathrm{C}$ of other chironomid groups. Furthermore, they found that $\delta^{13} \mathrm{C}$ of Chironomini was strongly

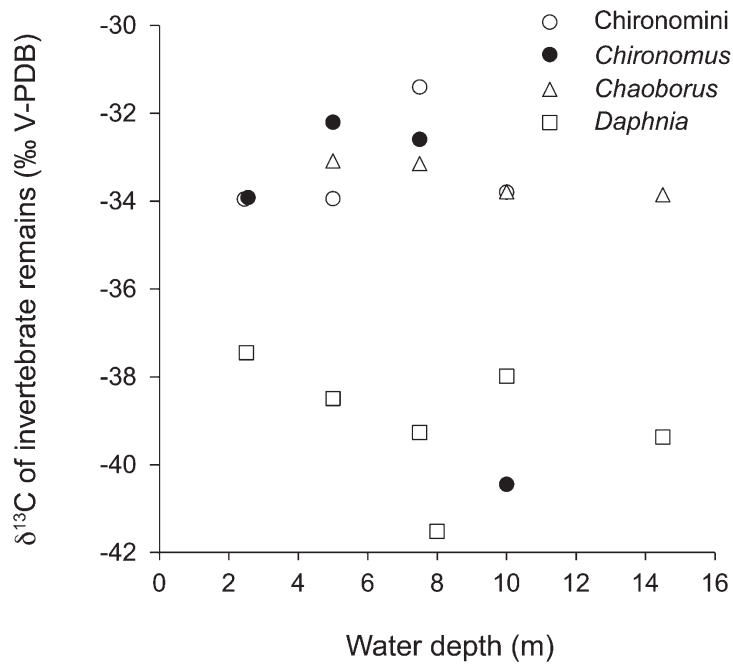

Figure 4. $\delta^{13} \mathrm{C}$ values of the chitinous remains of chironomids and other aquatic invertebrates (Daphnia, Chaoborus) isolated from surface sediments obtained at different water depths in lake De Waay, a seasonally anoxic and dimictic lake in the Netherlands.

and significantly correlated with methane flux measured at the surface of the study lakes (Figure 3B), whereas $\delta^{13} \mathrm{C}$ of other chironomid groups such as the Tanytarsini, Tanypodinae and Orthocladiinae was not as strongly, or not at all, related to methane flux. Van Hardenbroek et al. (2012a) caution that their results should be reproduced in additional lakes and that their interpretations are based on a relatively small dataset. However, their results also suggest that different chironomid groups may have different susceptibilities for their $\delta^{13} \mathrm{C}$ to be influenced by the presence and abundance of methane, with the Chironomini the group most prone to incorporating carbon from methane in lakes with high methane availability. A more extensive study of the relationship between methane flux in lakes and $\delta^{13} \mathrm{C}$ of invertebrate remains, based on samples from both Sweden and Northeast Siberia (van Hardenbroek et al. 2012b), recently confirmed the initial findings of van Hardenbroek et al. (2012a). In contrast to studies on chironomid $\delta^{18} \mathrm{O}$, the influence of the isotopic composition of inorganic sources of carbon in lakes on the isotopic composition of chironomids has not yet been explored. For example it is presently unclear how closely chironomid $\delta^{13} \mathrm{C}$ is related to $\delta^{13} \mathrm{C}$ of dissolved inorganic carbon or of methane.

Although the available ecosystem-scale studies highlight the potential of carbon and oxygen isotopic analyses for reconstructing past climatic variations and ecosystem processes, it is clear that further research at the ecosystem scale is necessary to understand, calibrate and expand the approaches. For example, the amplitude and timing of changes in both $\delta^{13} \mathrm{C}$ and $\delta^{18} \mathrm{O}$ throughout the year in inorganic and organic compartments of lake ecosystems, and the influence of this variability on chironomid larvae, is still poorly explored. Similarly the effects of these variations on the stable isotopic 
composition of fossil assemblages in different parts of lake basins remain to be examined in detail. For example, it is known that sampling depth and location within a lake basin can influence the performance of other approaches to palaeoecological reconstruction (e.g., Heiri et al. 2003). The few available surveys examining the variability of $\delta^{13} \mathrm{C}$ of invertebrate remains within lakes suggest that sampling depth and location may affect measurements of stable isotopes in invertebrate remains as well (van Hardenbroek et al. 2012a; Figure 4).

\section{Down-core records}

At present few records are available describing past changes in the stable isotopic composition of chironomid remains. Wooller et al. (2004) described two chironomid-based reconstructions of past temperature changes, each based on both chironomid $\delta^{18} \mathrm{O}$ analyses and changes in the taxonomic composition of the chironomid assemblages. The first record, originating from Qipisarqo Lake, Greenland, indicates millennial-scale variations in both $\delta^{18} \mathrm{O}$ and chironomid-inferred surface water temperature during the past ca. 8500 years. Both approaches suggest a warmer climate during the earlier part of the record, although $\delta^{18} \mathrm{O}$ values indicate a slightly earlier and more pronounced cooling than estimates based on the taxonomic composition of the Chironomidae (Figure 5A). For a second record from Fog Lake, Baffin Island, characterized by a major unconformity, Wooller et al. (2004) produced similar results. Chironomid $\delta^{18} \mathrm{O}$ reconstructs different temperatures for different sections of the sediment record, with relatively high values recorded before ca. 32,000 years BP and after ca. 8000 calibrated radiocarbon years BP (cal. BP). In an intercalated section representing ca. 11,000 to $8000 \mathrm{cal}$. BP, $\delta^{18} \mathrm{O}$ was very variable but in general typical for a cooler climate. Reconstructed temperatures based on the taxonomic composition of chironomid assemblages roughly followed these variations but indicated consistently cool temperatures between ca. 11,000 and $8000 \mathrm{cal}$. BP. These records demonstrate both the potential and problems associated with this combined approach based on chironomid $\delta^{18} \mathrm{O}$ and taxonomic changes in the chironomid assemblages. The two approaches can support and strengthen each other in sections of the record where inferred changes in temperatures are synchronous and run parallel. However, lake water $\delta^{18} \mathrm{O}$ is not only related to past annual air temperatures but can be strongly influenced by other local and climatic effects as for example evaporation of lake water and changes in the seasonality of precipitation. Furthermore, it can be expected that lake water $\delta^{18} \mathrm{O}$ does not only reflect summer conditions and the parameter therefore likely records a different seasonal component of past temperature change than the changes in chironomid assemblage composition, which are typically interpreted to reflect conditions during the summer months. In sections of sediment records where chironomid $\delta^{18} \mathrm{O}$ and assemblage based approaches suggest a diverging pattern of climatic change this may be because $\delta^{18} \mathrm{O}$ is affected by evaporative effects or by seasonally variable changes in past temperatures.

In a different study Verbruggen et al. (2010b) examined $\delta^{18} \mathrm{O}$ of the remains of chironomid larvae preserved in lateglacial sediments from Rotsee, Switzerland. The site had previously been studied for $\delta^{18} \mathrm{O}$ of lacustrine carbonates and, as a consequence, past variations in $\delta^{18} \mathrm{O}$ of the water in Rotsee were relatively well constrained. Verbruggen et al. (2010b) were able to show that chironomid $\delta^{18} \mathrm{O}$ closely followed the expected trends in lake water $\delta^{18} \mathrm{O}$ inferred from the lacustrine carbonate record (Figure $5 b$ ). Minor differences in variations of $\delta^{18} \mathrm{O}$ between the two records were to be expected since $\delta^{18} \mathrm{O}$ of precipitating
A

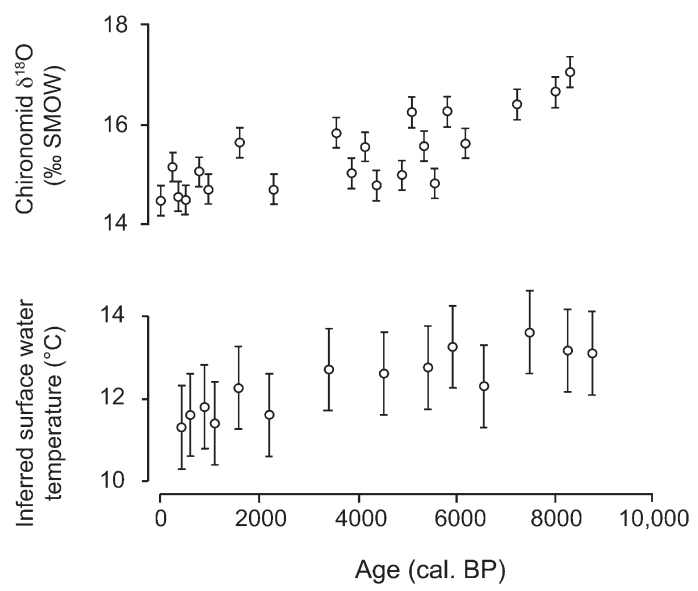

B

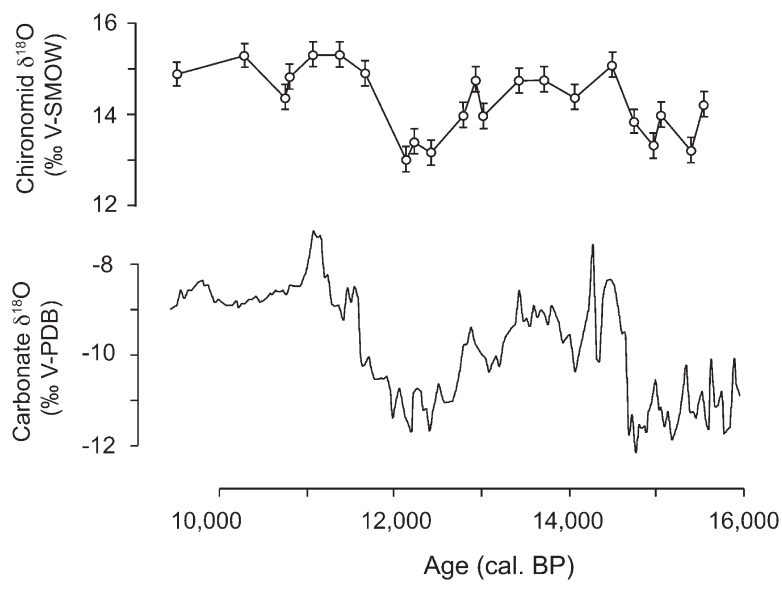

Figure 5. Examples of down-core records of stable isotopic compositions of chironomid remains. A) $\delta^{18} \mathrm{O}$ of chironomid remains isolated from the sediments of Qipisarqo Lake, Greenland, compared with reconstructed surface water temperature based on taxonomic changes in the chironomid assemblages (redrawn from Wooller et al. 2004). B) $\delta^{18} \mathrm{O}$ of chironomid remains and of carbonate in the late glacial sediments of Rotsee, Switzerland (redrawn from Verbruggen et al. 2010b). 
carbonates is strongly influenced by the temperature of ambient lake water, whereas no direct temperature effect is expected on $\delta^{18} \mathrm{O}$ during formation of chironomid cuticles. The results of Verbruggen et al. (2010b) demonstrate that chironomid $\delta^{18} \mathrm{O}$ can accurately follow past changes in lakewater $\delta^{18} \mathrm{O}$ and that the approach provides a viable alternative for producing $\delta^{18} \mathrm{O}$ records at sites lacking carbonates.

Wooller et al. (2008) presented multiple stable isotope records based on fossil chironomid remains from Stora Vidarvatn, a lake in north eastern Iceland. The authors were able to demonstrate that the lake experienced distinct changes in $\delta^{18} \mathrm{O}$, suggesting that it has been exposed to large variations in climate during the past ca. 12,000 years. Since changes in chironomid $\delta^{18} \mathrm{O}$ did not co-vary with changes of $\delta^{13} \mathrm{C}$ and $\delta^{15} \mathrm{~N}$ of the chironomid remains, the authors concluded that variations in diet were not driving the shifts in chironomid $\delta^{18} \mathrm{O}$. The authors discussed the possible implications of past changes in air mass trajectories over northeast Iceland and variations in precipitation seasonality for lake-water $\delta^{18} \mathrm{O}$. Furthermore, they again compared chironomid $\delta^{18} \mathrm{O}$ with a temperature reconstruction for Stora Vidarvatn based on past changes in chironomid taxonomic composition.

Wooller et al. (2012) and van Hardenbroek et al. (2012b) recently presented down-core records of fossil invertebrate $\delta^{13} \mathrm{C}$ from arctic lakes in Alaska and Northeast Siberia, respectively. Wooller et al. (2012) analysed $\delta^{13} \mathrm{C}$ and $\delta^{18} \mathrm{O}$ of chironomid head capsules and $\delta^{13} \mathrm{C}$ of ephippia of Daphnia. Whereas chironomid $\delta^{13} \mathrm{C}$ only showed relatively minor changes over the length of the 12,000 year record, Daphnia ephippia were characterized by larger variations and very depleted $\delta^{13} \mathrm{C}$ values as low as $-39 \%$ in some sections of the record. The authors interpret major changes in the carbon isotopic composition of these remains as indicative of intermittent phases of higher methane release from the studied lake. Van Hardenbroek et al. (2012b) analysed $\delta^{13} \mathrm{C}$ of the head capsules of different chironomid groups (Chironomini, Chironomus, Orthocladiinae, Tanypodinae, and Tanytarsini), and of Daphnia ephippia. In their record, $\delta^{13} \mathrm{C}$ of some chironomid groups remained relatively stable during the past ca. 1000 years. In contrast, the carbon isotopic composition of groups known to be able to feed on methane oxidizing bacteria, such as the Chironomini and Daphnia, showed marked variations. Van Hardenbroek et al. (2012b) interpreted this as indicating past changes in methane availability within the lake, leading to an enhanced uptake of methanogenic carbon in some invertebrate groups when methane was more abundant in the lake.

Griffiths et al. (2010) analyzed $8^{15} \mathrm{~N}$ in fossil chironomid remains of two arctic ponds strongly influenced by sea bird colonies. The $\delta^{15} \mathrm{~N}$ values in chironomid remains tracked overall changes in $\delta^{15} \mathrm{~N}$ of bulk organic matter. However, since variations in $\delta^{15} \mathrm{~N}$ of Daphnia remains in the sediment sequence indicated a different development of lake water $\delta^{15} \mathrm{~N}$, the authors concluded that further studies would be necessary to determine what influences the stable nitrogen isotopic composition in these invertebrate remains.

\section{CONCLUSIONS}

The limited number of datasets and surveys presently available that study the stable isotopic composition of chironomid remains indicate that the approach has the potential to provide reconstructions of both climatic changes (e.g., based on $\delta^{18} \mathrm{O}$ and $\delta \mathrm{D}$ analyses) and ecosystem processes (e.g., based on $\delta^{13} \mathrm{C}$ and $\left.\delta^{15} \mathrm{~N}\right)$. However, it is also clear that additional efforts are necessary to improve the methodology and further refine the datasets and information needed to reliably interpret downcore chironomid stable isotope records. Additional experiments will be necessary to increase our understanding of the effects of pretreatments on the stable isotopic composition of fossil chironomid remains, and to better constrain the relationship between the isotopic composition of lake water and food ingested by the larvae and the stable isotopic composition of their tissue and fossilizing structures. Ideally such experiments would be based on a range of chironomid species from different subfamilies or different feeding guilds in order to assess the extent to which the results are affected by differences in metabolism and behaviour. Furthermore, it will be essential to improve our understanding of the seasonal changes in the stable isotopic composition of chironomid larvae and of how this seasonality influences the stable isotopic values measured on fossil samples. As the examples discussed in this review have demonstrated, both laboratory based methodological and rearing experiments and ecosystem-scale, multi-site studies relating the stable isotopic composition of individual taxa and larval assemblages to environmental parameters of interest are necessary to further develop the approach. This will allow more closely constrained inferences of past environmental conditions in and around lakes based on the analysis and interpretation of stable isotopes in fossil chironomids.

\section{ACKNOWLEDGMENTS}

During the past years a number of colleagues has significantly supported our research and provided valuable feedback on our thoughts on and interpretations of stable isotopes in chironomid remains, including André F. Lotter, Frederike Verbruggen, Paul Bodelier, Jonathan Grey, and Matt Wooller. We also thank Tjerk Veenstra for his support in developing the data used for Figure 4, and two anonymous reviewers for valuable comments on an earlier version of this article. The authors acknowledge financial support by the European Research Council Starting Independent Researcher Grant project RECONMET (Project nr. 239858). 


\section{REFERENCES}

Beaudoin CP, Prepas EE, Tonn WM, Wassenaar LI, Kotak BG. 2001. A stable carbon and nitrogen isotope study of lake food webs in Canada's Boreal Plain. Freshwater Biology 46: 465477.

Bennike O, Brodersen KP, Jeppesen E, Walker IR. 2005. Aquatic invertebrates and high-latitude palaeolimnology. In: Pienitz R, Douglas MSV, Smol JP (eds). Long-term Environmental Change in Arctic and Antarctic Lakes. Developments in Paleoenvironmental Research, Volume 8. Dordrecht. Kluwer Academic Publishers. pp 117-157.

Borderelle AL, Gilmette C, Lovy C, Gerdeaux D, Verneaux V. 2008. Macroinvertebrate $\delta^{13} \mathrm{C}$ variability analysis for the assessment of lake trophic functioning. Fundamental and Applied Limnology 172: 289-300.

Brandriss ME, O'Neil JE, Edlund MB, Stoermer EF. 1998. Oxygen isotope fractination between diatomaceous silica and water. Geochimica et Cosmochimica Acta 62: 1119-1125.

Brodersen KP, Bennike O. 2003. Interglacial Chironomidae (Diptera) from Thule, Northwest Greenland: matching modern analogues to fossil assemblages. Boreas 32: 560-565.

Brodersen KP, Quinlan R. 2006. Midges as paleoindicators of lake productivity, eutrophication and hypolimnetic oxgen. Quaternary Science Reviews 25: 1995-2012.

Brooks SJ. 2006. Fossil midges (Diptera: Chironomidae) as palaeoclimatic indicators for the Eurasian region. Quaternary Science Reviews 25: 1894-1910.

Brooks SJ, Langdon PG, Heiri O. 2007. The identification and use of Palaearctic Chironomidae larvae in palaeoecology. Quaternary Research Association Technical Guide 10: 1-276.

Deines P, Bodelier PLE, Eller G. 2007a. Methane-derived carbon flows through methane-oxidizing bacteria to higher trophic levels in aquatic systems. Environmental Microbiology 9: 11261134.

Deines P, Grey J, Richnow H-H, Eller G. 2007b. Linking larval chironomids to methane: seasonal variation of the microbial methane cycle and chironomid $\delta^{13} \mathrm{C}$. Aquatic Microbial Ecology 46: 273-282.

Eggermont H, Heiri O. 2012. The chironomid-temperature relationship: expression in nature and palaeoenvironmental implications. Biological Reviews 87: 430-456.

Frey DG. 1988. Littoral and offshore communities of diatoms, cladocerans, and dipterous larvae, and their interpretation in paleolimnology. Journal of Paleolimnology 1: 179-191.

Goedkoop W, Åkerblom N, Demandt MH. 2006. Trophic fractionation of carbon and nitrogen stable isotopes in Chironomus riparius reared on food of aquatic and terrestrial origin. Freshwater Biology 51: 878-886.

Grey J. 2006. The use of stable isotope analyses in freshwater ecology: Current awareness. Polish Journal of Ecology 54: 563-584.

Grey J, Kelly A, Jones RI. 2004a. High intraspecific variability in carbon and nitrogen stable isotope ratios of lake chironomid larvae. Limnology and Oceanography 49: 239-240.

Grey J, Kelly A, Ward S, Sommerwerk N, Jones RI. 2004b. Seasonal changes in the stable isotope values of lake-dwelling chironomid larvae in relation to feeding and life cycle variability. Freshwater Biology 49: 681-689.
Griffiths K, Michelutti N, Blais JM, Kimpe LE, Smol JP. 2010. Comparing nitrogen isotopic signals between bulk sediments and invertebrate remains in High Arctic seabird-influenced ponds. Journal of Paleolimnology 44: 405-412.

Harrod C, Grey J. 2006. Isotopic variation complicates analysis of trophic relations within the fish community of Plusssee: a small, deep, stratifying lake. Archiv für Hydrobiologie 167: 281-299.

Heiri O, Birks HJB, Brooks SJ, Velle G, Willassen E. 2003. Effects of within-lake variability of fossil assemblages on quantitative chironomid-inferred temperature reconstruction. Palaeogeography, Palaeoclimatology, Palaeoecology 199: 95106.

Herzschuh U, Mischke S, Meyer H, Plessen B, Zhang C. 2010. Using variations in the stable carbon isotope composition of macrophyte remains to quantify nutrient dynamics in lakes. Journal of Paleolimnology 43: 739-750.

Jones RI, Carter CE, Kelly A, Ward S, Kelly DJ, Grey J. 2008. Widespread contribution of methane-cycle bacteria to the diets of lake profundal chironomid larvae. Ecology 89: 857-864.

Kiyashko SI, Narita T, Wada E. 2001. Contribution of methanotrophs to freshwater macroinvertebrates: evidence from stable isotope ratios. Aquatic Microbial Ecology 24: 203-207.

Last WM, Smol JP (eds). 2001. Tracking environmental change using lake sediments. Basin analysis, coring, and chronological techniques. Dordrecht. Kluwer Academic Publishers. 548 p.

Leavitt SW, Danzer SR. 1993. Method for batch processing small wood samples to holocellulose for stable-carbon isotope analysis. Analytical Chemistry 65: 87-89.

Leavitt PR, Brock CS, Ebel C, Patoine A. 2006. Landscape-scale effects of urban nitrogen on a chain of freshwater lakes in central North America. Limnology and Oceanography 51: 2262-2277.

Leng M, Barker PA. 2006. A review of the oxygen isotope composition of lacustrine diatom silica for palaeoclimate reconstruction. Earth-Science Reviews 75: 5-27.

Leng MJ, Marshall JD. 2004. Palaeoclimate interpretation of stable isotope data from lake sediment archives. Quaternary Science Reviews 23: 811-831.

Meyers PA, Lallier-Vergès E. 1999. Lacustrine sedimentary organic matter records of Late Quaternary paleoclimates. Journal of Paleolimnology 21: 345-372.

Minagawa M, Wada, E 1984. Stepwise enrichment of $\delta^{15} \mathrm{~N}$ along food chains: further evidence and the relationship between $\delta^{15} \mathrm{~N}$ and animal age. Geochimica et Cosmochimica Acta 48: 1135-1140.

Nielson KE, Bowen GJ. 2010. Hydrogen and oxygen in brine shrimp chitin reflect environmental water and dietary isotopic composition. Geochimica et Cosmochimica Acta 74: 18121822 .

Pel R, Hoogveld H, Floris V. 2003. Using the hidden isotopic heterogeneity in phyto- and zooplankton to unmask disparity in trophic carbon transfer. Limnology and Oceanography 48: 2200-2207.

Post DM. 2002. Using stable isotopes to estimate trophic position: models, methods and assumptions. Ecology 83: 703-718.

Ravinet M, Syväranta J, Jones RI, Grey J. 2010. A trophic pathway from biogenic methane supports fish biomass in a temperate lake ecosystem. Oikos 119: 409-416.

Saether OA. 1979. Chironomid communities as water quality indicators. Holarctic Ecology 2: 65-74. 
Schimmelmann A. 2011. Carbon, nitrogen and oxygen stable isotope ratios in chitin. In: Gupta NS (ed). Chitin. Springer Netherlands, pp 81-103.

van Hardenbroek M, Heiri O, Grey J, Bodelier PLE, Verbruggen F, Lotter AF. 2010. Fossil chironomid $\delta^{13} \mathrm{C}$ as a proxy for past methanogenic contribution to benthic food webs in lakes? Journal of Paleolimnology 43: 235-245.

van Hardenbroek M, Heiri O, Wilhelms MF, Lotter AF. 2011. How representative are subfossil assemblages of Chironomidae and common benthic invertebrates for the living fauna of Lake De Waay, the Netherlands? Aquatic Sciences 73: 247-259.

van Hardenbroek M, Lotter AF, Bastviken D, Duc NT, Heiri O. 2012a. Relationship between $\delta^{13} \mathrm{C}$ of chironomid remains and methane flux in Swedish lakes. Freshwater Biology 57: 166-177 van Hardenbroek M, Heiri O, Parmentier FJW, Bastviken D, Ilyashuk BP, Wiklund JA, Hall RI, Lotter AF. 2012b. Evidence for past variations in methane availability in a Siberian thermokarst lake based on $\delta^{13} \mathrm{C}$ of chitinous invertebrate remains. Quaternary Science Reviews doi:10.1016/j.quascirev.2012.04.009

Verbruggen F, Heiri O, Reichart GJ, De Leeuw JW, Nierop KGJ, Lotter AF. 2010a. Effects of chemical pretreatments on $\delta^{18} \mathrm{O}$ measurements, chemical composition, and morphology of chironomid head capsules. Journal of Paleolimnology 43: 857-872.

Verbruggen F, Heiri O, Reichart GJ, Lotter AF. 2010b. Chironomid $\delta^{18} \mathrm{O}$ as a proxy for past lake water $\delta^{18} \mathrm{O}$ : a Lateglacial record from Rotsee (Switzerland). Quaternary Science Reviews 29: 2271-2279.

Verbruggen F, Heiri O, Reichart GJ, Blaga C, Lotter AF. 2011. Stable oxygen isotopes in chironomid and cladoceran remains as indicators for lake-water $\delta^{18} \mathrm{O}$. Limnlogy and Oceanography 56: 2071-2079.

von Grafenstein U, Erlenkeuser H, Trimborn P. 1999. Oxygen and carbon isotopes in modern fresh-water ostracod valves: assessing vital offsets and autecological effects of interest for palaeoclimate studies Palaeogeography, Palaeoclimatology, Palaeoecology 148: 133-152.

Walker IR. 2001. Midges: Chironomidae and related Diptera. In: Smol JP, Birks HJB and Last WM (eds). Tracking Environmental Change Using Lake Sediments. Volume 4. Zoological Indicators. Dordrecht. Kluwer Academic Publishers. pp 43-66.

Walker IR, Cwynar LC. 2006. Midges and palaeotemperature reconstruction - the North American experience. Quaternary Science Reviews 25: 1911-1925.

Wang Y, Francis DR, O'Brien DM, Wooller MJ. 2008. A protocol for preparing subfossil chironomid head capsules (Diptera: Chironomidae) for stable isotope analysis in paleoclimate reconstruction and considerations of contamination sources. Journal of Paleolimnology 40: 771-781.

Wang YV, O'Brien DM, Jenson J, Francis D, Wooller MJ. 2009. The influence of diet and water on the stable oxygen and hydrogen isotope composition of Chironomidae (Diptera) with paleoecological implications. Oecologia 160: 225-233.

Whiticar MJ, Faber E, Schoell M. 1986. Biogenic methane formation in marine and freshwater environments: $\mathrm{CO}_{2}$ reduction vs. acetate fermentation - Isotope evidence. Geochimica et Cosmochimica Acta 50: 693-709.

Wiederholm T. 1984. Responses of aquatic insects to environmental pollution. In: Resh VH and Rosenberg DM (eds). The Ecology of
Aquatic Insects. New York. Praeger Publishers. pp 508-557.

Wolfe BB, Edwards TWD, Elgood RJ, Beuning KRM. 2001. Carbon and oxygen isotope analysis of lake sediment cellulose: methods and applications. In: Smol JP, Birks HJB and Smol JP (eds). Tracking Environmental Change Using Lake Sediments. Volume 2: Physical and Geochemical Methods. Dordrecht. Kluwer Academic Publishers. pp 373-400.

Wooller MJ, Francis D, Fogel ML, Miller U, Walker IR, Wolfe AP. 2004. Quantitative paleotemperature estimates from $\delta^{18} \mathrm{O}$ of chironomid head capsules preserved in arctic lake sediments. Journal of Paleolimnology 31: 267-274.

Wooller M, Wang YM, Axford Y. 2008. A multiple stable isotope record of Late Quaternary limnological changes and chironomid paleoecology from northeastern Iceland. Journal of Paleolimnology 40: 63-77.

Wooller MJ, Pohlman JW, Gaglioti BV, Langdon P, Jones M, Anthony KMW, Becker KW, Hinrichs K-U, Elvert M. 2012. Reconstruction of past methane availability in an Arctic Alaska wetland indicates climate influenced methane release during the past $\sim 12,000$ years. Journal of Paleolimnology 48: 27-42. 